\title{
SCHOOL PRINCIPALS' SELF-IDENTITY ACCORDING TO THE PERSPECTIVE OF TRANSPERSONAL PSYCHOLOGY
}

Akmal Mundiri and Umar Manshur

Fakultas Agama Islam

Universitas Nurul Jadid Paiton, Probolinggo, Jawa Timur email: akmalmundiri@gmail.com

Abstract: The school principal at the Pesantren, displays a unique self-image that distinguishes itself from the others. In the school principal's self-identity is attached to the appreciation of values that become the core beliefs and core values of the principal. This study uses a qualitative approach to the type of phenomenology. Thus, this study seeks to explore the phenomenon of identity formation or forms of identity in the perspective of transpersonal psychology. The results of this study indicate that the formation of principals-based principals' self-identity is carried out in the form of self-understanding, parenting style and role models. Whereas the principal's identity pattern based on Pesantren in the perspective of transpersonal psychology at pondok Pesantren Nurul Jadid is in the form of spiritual awareness and ability to manage the ego (trans-ego). Thus, this study generally describes findings of self-identity oriented to the nafsani substance in the form of integration of three forces, namely; the heart (fitrah ilahiyah) as a superconscious aspect that has emotional power; reason (fitrah insaniyah) as an aspect of consciousness that has the power of cognition; and lust (fitrah hayawaniah) as an aspect of the pre or unconscious that has the power of konasi.

الملخص: يعرض المديرالمدرسة المعهدية صورة ذاتية فريدة قيز نفسها عن الآخرين. في

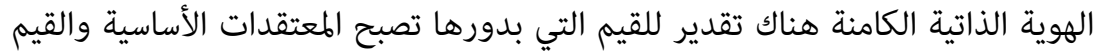

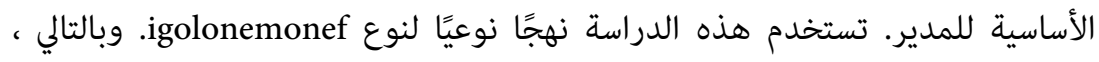

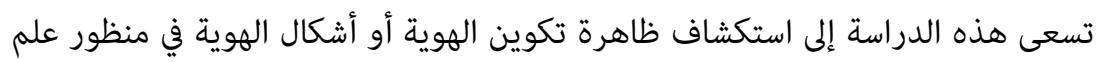

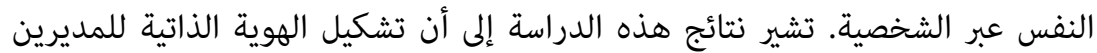


الذين يعتمدون على المبادئ يتم في شكل فهم الذات ، وأسلوب الوالدية وفاذج القدوة.

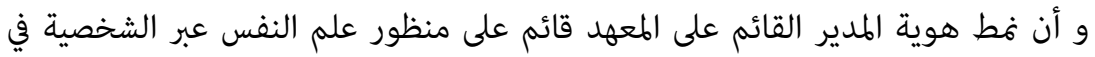

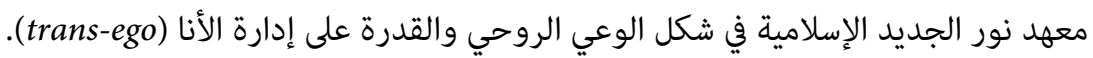

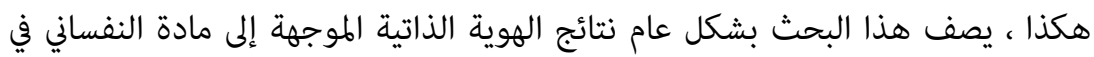

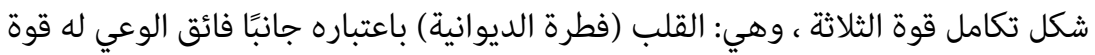

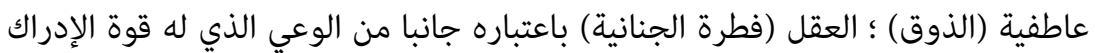

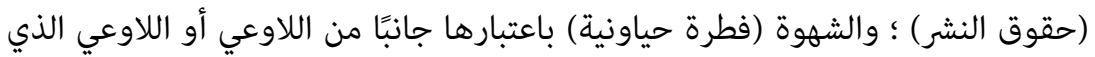
لديه قوة كوناسي (asrak). (حقوق)

Abstrak: Kepala sekolah di Pesantren menampilkan citra diri yang unik yang membedakan dirinya dengan yang lain. Dalam identitas diri kepala sekolah melekat suatu penghayatan nilai yang menjadi core belief dan core values pribadi kepala sekolah. Penelitian ini menggunakan pendekatan kualitatif dengan jenis fenomenologi.Dengandemikian, penelitian ini berupayamenggali fenomena pembentukan identitas ataupun bentuk identitas dalam perspektif psikologi transpersonal. Hasil penelitian ini menunjukkan bahwa pembentukan identitas diri kepala sekolah berbasis Pesantren dilakukan dalam bentuk self understanding, parenting style dan model figur panutan. Sedangkan pola identitas diri kepala sekolah berbasis Pesantren dalam perspektif psikologi transpersonal di pondok Pesantren Nurul Jadid berupa kesadaran spiritual dan kemampuan dalam mengelola ego (trans-ego). Penelitian ini secara umum menggambarkan temuan identitas diri yang berorientasi pada substansi nafsani yang berupa integrasi tiga daya, yaitu; kalbu (fitrah ilahiyah) sebagai aspek supra-kesadaran yang memiliki daya emosi (rasa); akal (fitrah insaniyah) sebagai aspek kesadaran yang memiliki daya kognisi (cipta); dan nafsu (fitrah hayawaniah) sebagai aspek pra atau bawah-sadar yang memiliki daya konasi (karsa).

Keywords: self-identity, school principals, Pesantren, transpersonal psychology. 


\section{INTRODUCTION}

Identity is indeed always at the core of the process of "becoming" in the continuum of social change. The study of identity is often carried out within the scope of political identity. ${ }^{1}$ Identity with all of its attributes has an impact on social life. Identity in this dimension has penetrated almost all lines of human life to the extent that it is related to human identity (self). Religious identity marked by the increasingly demonstrative of each religion in displaying identity at a certain point causes tensions that can give birth to social polarization, both between official and unofficial religions, the ethnicity of groups or ethnicity with one another. ${ }^{2}$

In the Pesantren as education system, religious identity is reflected in the leadership of the Kyai with such characteristics as frank, bold and outspoken in his attitude. The effects that arise due to the operation of the impact factor of personality and insight cause not all the children of Kyai are able to move the community or even cannot replace their position. The inability of the Kyai's descendants in continuing the leadership relay certainly also engulfed leaders in formal educational institutions in the Pesantren, who did not necessarily have the ability to be Kyai in leading. ${ }^{3}$

According to Bruinessen, moral values and Akhlak are part of the fundamental values internalized to Santri and are attached to a personal identity. Such internalized values then result in obedience, the totality of dedication, and respect for the Kyai and his descendants, other scholars and the authors of the text-books that are studied. For Santri, morality should come first before knowledge. Among the Santri, the concept of the position of knowledge and character is colored with heroic stories and devotion of the Santri to the Kyai which is believed as one of the factors of success of a Santri, also

1 Leni Winarni, "The Political Identity of Ulama in the 2014 Indonesian Presidential Election," Al-Jami 'ah: Journal of Islamic Studies 52, no. 2 (December 24, 2014): 257, https://doi.org/10.14421/ajis.2014.522.257-269.

2 Akmal Mundiri and Moch Tohet, "Contestation of Religious Identity in the Cyber World: A Case Study of Arrahmah.Com and VOA Islam Dealing with Religious Others on Facebook," Walisongo: Jurnal Penelitian Sosial Keagamaan 26, no. 2 (December 3, 2018): 391-416, https://doi.org/10.21580/ws.26.2.3244.uc0u8221 ..WWalisongo: Jurnal Penelitian Sosial Keagamaan 26, no. 2 (December 3, 2018

3 Hefniy Hefniy, "Pergeseran Kepemimpinan Kyai dalam Mengembangkan Budaya di Pondok Pesantren Nurul Jadid Paiton Probolinggo" (Disertasi, Malang, UIN Malang, n.d.), http://etheses.uin-malang.ac.id/12182/. 
becoming material for internalization of obedience and surrender. For the Kyai, Akhlak shown in obedience and submissiveness are inseparable parts of the Pesantren education. ${ }^{4}$

The school principal as a leader in a formal education institution under the auspices of the Pesantren represents himself as a leader whose lead formal education institution in Pesantren, which is certainly different from other formal education institutions. In the process of interaction between superiors and subordinates, leaders in Islamic educational institutions often have strong religious identities. In this case, the leader represents religious identity in the form of ideas and behavior and makes it as core beliefs and core values that are inherent in their personalities. However, often the behavior and ideas of leaders of educational institutions do not represent his position as the principal of an educational institution in a Pesantren. School principals as a second-leader next the Kyai should have a strong religious identity and not the other way around.

The identity of the school principal based on Pesantren is certainly built on the empirical reality of the principal's mental development, both in the form of meta-need, peak values, unitive consciousness, peak experience, b-values, mystical experience, self-actualization, self-transcendence, the essence of being unity, and so on. In representing their identity in terms of religiosity, religion becomes a personal matter and the experience of different diversity occurs in the principal. All port's notion of spirituality is inseparable from his grand idea of personality; that is, what is known as "becoming". Personality is not only understood from the origin of instinctive needs or environmental influences in the past. More important than that is the pattern of behavior and motivation that exists today. Although the personality is permanent in its existence, it is constantly changing, because it is a complex product of biological derivatives, cultural influences, styles of understanding, and spiritual search. ${ }^{5}$

The research on identity is indeed quite a lot, but in general tends to be directed at the life of traditionally classified communities

4 Martin van Bruinessen, Kitab Kuning, Pesantren, Dan Tarekat; Tradisi Islam (Bandung: Mizan, 1999), 19.

5 Robert W. Crapps, Gaya Hidup Beragama Autoritas yang Sedang Menjadi Mistik (Yogyakarta: Kanisius, 1993). 
such as Dayak, Sawu (Rote), Samin, Osing, Tongan, and so forth. The discussion on identity has not touched other issues such as the identity of urban communities or other social institutions. The facts that exist are enough to explain that the identity of urban communities or other social institutions tends to be more complex and have more combinations so that the identity politics of the community has not been discovered. Therefore, studies on identity politics are not relevant if only relying on knowledge from expert groups, but in this case, the study of identity politics that also relies on interactions with subjects of identity politics actors as well as direct experience with actors which in naturalistic research methodology is called hidden knowledge (tacit knowledge). ${ }^{6}$ Thus, this study aims to understand the process of forming the identity of the principals of the Pesantrenbased school and forms of identity of the principals of the Pesantren based school in the perspective of transpersonal psychology, giving the fact that the leadership identity of school principal in Pesantren is construed on the empirical reality of the development of the principal's soul, both in the form of meta-need, peak values, unitive consciousness, peak experience, b-values, mystical experience, selfactualization, self-transcendence, the essence of being unity, and etc. The authors are particularly interested in conducting research aimed at getting a description of self-identity of the school principal in Pesantren from the perspective of transpersonal psychology.

To achieve the research objectives, the authors use a qualitative design with a phenomenological approach. In this study, data were collected using observation techniques, depth interviews, and documentation. After the data collection, the researcher conducted data processing with Spradley data analysis techniques consisting of domain analysis, taxonomic analysis, componential analysis, and analysis of cultural themes. ${ }^{7}$ In order to produce credible data,

${ }^{6}$ Mundiri and Tohet, "Contestation of Religious Identity in the Cyber World."which are part of a new form of identity contestation in the cyber era. This study uses an ethnographic approach focusing on the beliefs, language, values, rituals, customs, and behavior of people who interact in the community as the object of research. Thus, this study portrays the phenomenon of contestation of religious identity, both in the process of forming the identity (personal identity

7 Emzir, Analisis Data: Metodologi Penelitian Kualitatif(Jakarta: Rajawali Pers, 2010), 131. 
the researchers used the triangulation technique as one of the data validity checking techniques.

\section{ESTABLISHMENT OF A SELF-IDENTITY OF HEADMASTER BASED ON PESANTREN}

Identity is an important part of self-concept that is not only a descriptive overview but also the assessment of self. The concept of self includes what we think and what we feel about ourselves. The concept of self is also defined as all we think and feel about us, the entire complex of beliefs and attitudes you hold about yourself. All individual thoughts and feelings become a reference in forming selfconcept. Identity is a part of ourselves where we are known by others. An important way to explore identity is through peer interaction. Self-identity is a characteristic that is owned by someone and gives a clear difference about him with others. A person's social identity forms a self-concept and allows that person to put away in a certain position in a complex network of social relations. ${ }^{8}$ The concept of identity can also be seen from the cultural aspect in the dimension of emotional significance, which makes a person attached to a thing, which distinguishes it from others so that it is easier to be recognized. The purpose of this identity is to make and build communication. ${ }^{9}$ Based on the results of research conducted at the Pesantren Nurul Jadid Paiton Probolinggo, it was found that the process self-identity construction of the school principals in the Pesantren Nurul Jadid was carried out in the form of;

\section{Self-identity based on self-understanding}

Self understanding is an attempt to understand oneself that is intimate and direct. This is accommodated in the second source which is considered authoritative in answering the religious problems of Muslims in the form of than 'arafa nafsahu, faqad arafa rabbahu, which means that "a person who knows himself, will know his Rabb".

8 Sarlito Wirawan Sarwono, Psikologi Sosial Psikologi Kelompok dan Psikologi Terapan (Jakarta: Balai Pustaka, 1999), 15.

9 Primada Qurrota Ayun, "Fenomena Remaja Menggunakan Media Sosial Dalam Membentuk Identitas," CHANNEL Jurnal Komunikasi 3, no. 2 (October 1, 2015), https://doi.org/10.12928/channel.v3i2.3270. 
The hadith serves as a guide for Pesantren and the principal leaders in its formal education institutions. ${ }^{10}$

Self-understanding, or better known as self-concept, is one of the factors forming the identity of the principals in Pesantren Nurul Jadid Paiton Probolinggo. Understanding of religious sacred text is the most important forming factor of identity in Pesantren because recognition marked by an understanding of self-identity is a key opening element to the recognition of God. According to one of the principals in the Pondok Pesantren Nurul Jadid, the religious doctrine has a broad horizon, which is the source of value in forming personality, ideology for social movements, and the glue of social relations. Any religious doctrine adhered to or by any community on this earth teaches its adherents to be good human beings, to have integrity and compassion, to love peace and hate violence, and so forth. Substantially the religious teachings provide a strict framework of norms for the behavior of the people, it is almost difficult to find religious doctrines of revelation that do not teach good things to its followers. Therefore, the founder of this pesantren established the trilogy and five students' awareness which he formulated as a guide for all santri of Nurul Jadid which are based on religious values. ${ }^{11}$

Thus, self identity of the principals of the Pesantred-based school in Pesantren Nurul Jadid Paiton Probolinggo is shaped from self-understanding in the form of an introduction and understanding of the principals' self-potential. The form in this dimension is a manifestation of the practice of the second authoritative source believed by the principal of Pesantren-based school. Thus, the formation of identity in this dimension makes a person know and appreciate himself as a person and not immersed in the role he playes, for example as a child, friend, student, or colleague.

The process of forming identity with self-recognition and understanding of the school principal in the Pesantren is key components of self-introduction. Jacques Lacan, a psychoanalyst from France, argues that the initial recognition of self-identity comes when a person experiences what is called the mirror phase. The mirror

${ }^{10}$ Didik Wicaksono, Interview data, July 12, 2019.

${ }^{11}$ Thohiruddin Thohiruddin, Interview data, July 12, 2019. 
phase takes place in the form of a division between me who sees and me who is seen. ${ }^{12}$

The mirror phase is carried out in the school principal's educational process that has been passed before. The next phase is one of the factors forming the self-awareness of the school principal. In the process of identity formation that takes place in Pesantren, according to Abdurrahman Wahid, there are two main elements, firstly, imitation, in the form of efforts to transfer the life patterns of the sabbates, tabi'in and tabi 'tabi'in into the attitude, thoughts, and behavior of the Pesantren live. This is reflected in the books that Pesantren use, the totality of observance of worship, nrimo culture, and so on; Second, restraints (ostracization) that manifest in strict social discipline in Pesantren. Social discipline in this case is in the form of loyalty in implementing the Pesantren life patterns as in the books of fiqh and Sufism. Loyalty to Pesantren is the main basis in discipline and exclusion or punishments for those who disobey are two consequences for the restraining mechanism used. The imitation and restraint that occurred in the Pesantren which became the locus of this study emphasized more on the alignment of vertical and horizontal relationships.

The religious doctrine in forming self-understanding of the Pesantren-based school principals in Pesantren Nurul Jadid is strongly engraved in the Trilogy and five awareness of Santri in Pesantren Nurul Jadid. The trilogy and the five students' awareness which is a concept formulated by the founder of the pondok Pesantren Nurul Jadid Paiton Probolinggo become the main norm that must exist and implemented by all institutions and human resources under the auspices of the pesantren. Trilogy norms that emphasize the obligations of fardhu ain, avoid great sins and manners to God and His creation become an indisputable norm that must be engraved in feelings and actions. Whereas in religious awareness, there are three components that must be owned by Santri of Pesantren Nurul Jadid, namely the aspects of faith (aqidah), worship and morals.

Therefore, Pesantren Nurul Jadid makes religion the standard of organizational culture ethics for all educational institutions in Pesantren. Thus, it is clear that the relationships between individuals

${ }^{12}$ Erik Erikson and Agus Cremers, Identitas dan Siklus Hidup Manusia: (Bunga Rampai 1) (Jakarta: PT Gramedia, 1989), 30-32. 
as members of a group are not merely based on agreements, existing regulations and successfully created patterns of behavior that have been mutually agreed upon. However, the most important thing in the continuity of the relationship is the religious values of each member which is then manifested in shared patterns of behavior and norms. These behaviors and norms gradually necessitated the formation of self-understanding that became the core values of Pesantren-based principals and eventually became a personal identity that distinguishes them from other principals outside Pesantren.

The process of forming the principals' identity of the Pesantren in the dimension of forming self-understanding also results from self-awareness that any work or duties performed by Santri is a kind of tabarrukan (seeking blessings) to the Kyai at the Pesantren. The principals of the school in pondok Pesantren Nurul Jadid make the figure of the Kyai as a role model in various ways which is caused by Santri's trust in the blessing of the Kyai. In pesantren which makes Ahlusunnah as an Aqidah, the term of barokah is quite familiar. Educators in the Pesantren still believe and consider themselves as Santri (dados santri). It has implications for the belief that carrying out the orders of the Kyai or Pesantren will get a blessing.

The belief in religion that calls for faith and amal shaleh makes pesantren has a distinctive belief system sourced from religious dogma and ultimately become life's outlook and guidance (weltanschauung). In this case, individuals in Pesantren have played their actual role as implementer of God's message on earth. Likewise, based on the history of the establishment of Pesantren, according to Abdurrahman Wahid is a form of reaction to certain lives that are considered vulnerable so that Pesantren naturally undergo a process of cultural transformation and become an alternative to existing life patterns. ${ }^{13}$ Based on that description, the process of self-identity formation in Pesantren involves the aspects of religiosity among the principals in Pesantren Nurul Jadid. Among the aspects of religiosity, namely; a sense of appreciation, practice, experience, and attachment that individuals have to whatever is taught religion and based on faith.

The description above is in accordance with what was revealed by Clifford Geertz as revealed by Daniel L. Pals that religion is a

${ }^{13}$ Abdurrahman Wahid, Menggerakkan Tradisi: Esai-Esai Pesantren, Cet. 1 (Yogyakarta: LKis, 2001), 12. 
symbol system that aims to create strong, contagious, and persistent feelings and motivations in a person by forming a conception of a general order of existence and attaching this conception to factual emanations, and ultimately these feelings and motivations will be seen as a unique reality. ${ }^{14}$ Thus, this study found that belief in religious values did not become a dead symbol, but furthermore enter into the heartstrings of the school principals at the Pesantren Nurul Jadid. Belief in religion creates strong and persistent feelings and motivations. Thus, religion causes someone to feel or do something and makes the values in religiosity as motives that drive behavior.

The explanation as above, confirms that self-understanding in forming the school principals self-identity is raising the existence of spiritual awareness. The spiritual awareness according to Sanerya Hendrawan is a result of; first, the tendency of humans to start looking for a holistic meaning (wholeness) or meaning greater than themselves (beyond self); second, as a choping mechanism in dealing with major crises that are outside the limits of the power of soul endurance in work life by relying on something greater than themselves; third, as an evolutionary tendency of personality development towards peak human experience in immaterial and transcendental extracts, from life only has to to live on the level of being (to be). ${ }^{15}$

The process of identity formation of the Pesantren-based school is carried out in the dimension of spiritual experience that is indeed interwoven in the Pesantren. ${ }^{16}$ These spiritual experiences are then deeply felt and even transform life. The process of finding, nurturing, and rediscovering something meaningful is the essence of spirituality. Spirituality has a different shape for each person depending on a combination of biological, social, psychosocial, situational, and transcendental forces. Someone who finds the root meaning of his life will try to maintain his relationship with God and looked at every aspect of his life based on the relationship he builds with God. The various virtues and strengths arise through this relationship. Building a life of spirituality cannot be separated from

${ }^{14}$ Daniel L Pals, Seven Theories of Religion (Yogyakarta: IRCISoD, 2011), 342.

${ }^{15}$ Sanerya Hendrawan, Spiritual Management; From Personal Enlighment Towards God Corporate Governance (Bandung: Mizan, 2009), 11.

${ }^{16}$ Nurochim Nurochim, "Sekolah Berbasis Pesantren Sebagai Salah Satu Model Pendidikan Islam Dalam Konsepsi Perubahan Sosial," Al-Tahrir: Jurnal Pemikiran Islam 16, no. 1 (June 24, 2016): 69, https://doi.org/10.21154/al-tahrir.v16i1.320. 
building relationships with something meaningful. Thus, in order to build a life of spirituality based on self-understanding, someone can use the method of determining boundaries (marking boundaries), spiritual purification, spiritual mindset (spiritual reframing) as the following picture:

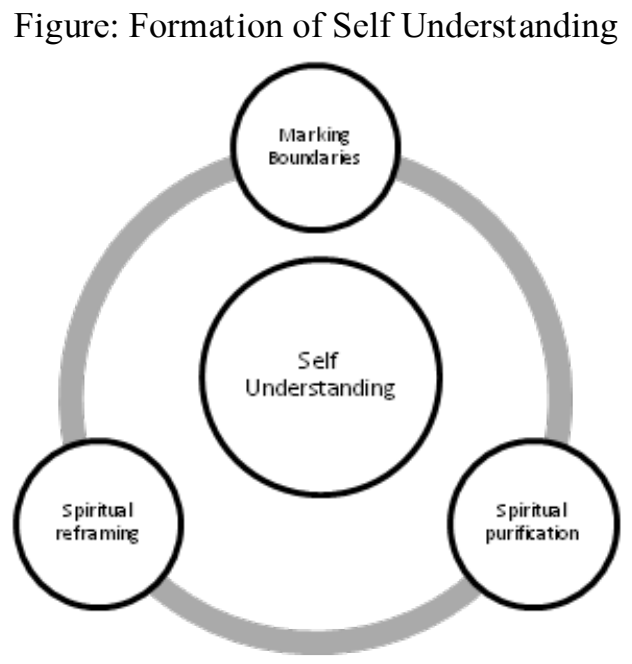

\section{Self-identity formation based on parenting style}

In addition to the dimension of self-understanding which is a factor forming the school principals' self-identity, parenting patterns also become an inseparable part of the process of forming the self-identity. Parenting is a description of the attitudes and behavior of parents with children in interacting and communicating during parenting activities. The pattern of parenting as a parent's responsibility to the child, by having a big impact on the child's personality, because what is imitated by the child is derived from both parents.

Based on the research, it was found that the formation of the school principals' self-identity in Pesantren Nurul Jadid was also caused by good parenting conducted by parents, teacher parenting, or Kyai in previous education. Based on data obtained from the documentation, it was found that all school principals in the Pesantren 
Nurul Jadid have had experience as a Santri at the Pesantren. ${ }^{17}$ The pattern of parenting in the Pesantren is carried out jointly between parents as the guardian of the Santri, Kyai, and Pesantren teacher. Collaboration in the parenting process makes it easier to internalize the values of pesantren.

The pattern of parenting that contributes to the formation of the school principals' self-identity is unconsciously caused by the operation of the collaborative parenting between parents, teachers, Pesantren teachers, and Kyai. The school principals at the Pesantren Nurul Jadid are those who have been as Santri in this Pesantren, have experienced the twists and turns of development, and participated in following the development of Pesantren and its formal institutions. Thus, Pesantren is a sacred place for the process of education and childcare. ${ }^{18}$ The uniqueness of the Pesantren education process confirms that the Pesantren as one of the candradimuka craters is the formation of religiosity in the leader, which is reflected in the identity of the "Santri" which is always a source of pride for those who have been educated or have grown in the Pesantren.

The parenting pattern is an external factor in forming the school principals' self-identity in Pesantren, which starts when he became a Santri until he served as a principal in a Pesantren environment. The formation of self-identity through parenting style is carried out through a strict mechanism that is different from educational patterns outside Pesantren. The parenting pattern in Pesantren in forming the school principals' self-identity in Pesantren is not only done through the exemplary of the main Pesantren figures but also through restraints (ostracization). ${ }^{19}$ The restraints carried out by the Pesantren as above, are in line with the regulations and daily schedule documents that must be carried out by the Santri. The regulations and obligations of the Santri are more focused on the fardlu ain aspect which is a further elaboration of the Trilogy and five awareness of Santri in the Pesantren Nurul Jadid. ${ }^{20}$ The caring style that is carried

${ }^{17}$ Pondok Pesantren Nurul Jadid, "Data Document about Alumni of Pondok Pesantren Nurul Jadid” (Pondok Pesantren Nurul Jadid, 2018).

${ }^{18}$ Faizin Syamweil, Interview data, July 13, 2019.

19 Thohiruddin, Interview data.

${ }^{20}$ Pondok Pesantren Nurul Jadid, "Data Document about Regulations and Obligations of Santri in Pondok Pesantren Nurul Jadid" (Pondok Pesantren Nurul Jadid, 2019). 
out together, both by the boarding school administrators, the clerics, and the family environment has also become one of the forming factors of school principals' self-identity. The self-identity is inherent until now as the school principal in Pesantren. ${ }^{21}$

The dynamics of the educational process in Pesantren, not only related to religious knowledge, but also other knowledge at the same level as schools outside the pesantren. The difference between schools outside the pesantren is only related to curriculum content which emphasizes the balance between religion and others knowledge. Therefore, the parenting style of Santri in growing characters is often done in the form of; ${ }^{22}$ exemplary, training and habituation, taking ibrah (learning from an event), educating with advice, educating through discipline, targhib and tadzhib. ${ }^{23}$ Whereas education that can be applied to children According to Abdullah Nashih Ulwan is to use: 1) the exemplary method; 2) habituation method; 3) method of attention; 4) the advice method; and 5) punishment method. ${ }^{24}$

\section{Self-identity formation based on exemplary method}

The process of forming the identity of school principal at the pondok Pesantren Nurul Jadid is also inseparable from the influence the role models that the principals admire. The school principals in Pesantren make Kyai as a role model in various ways. ${ }^{25}$ In the process of forming self-identity on this dimension, the principal makes the Kyai of Pesantren as the main models in speaking, behaving, and interacting. The example set by the Kyai is the most important method of education, both for children and adults. More influence is obtained from things that are practical than theoretical. The

${ }^{21}$ Akmal Mundiri and Syafiqiyah Adhimiy, Religious Authoritative Parenting Berbasis Quantum Meaningfullness of Life; Melejitkan Potensi Raih Prestasi (Probolinggo: Pustakan Nurja, 2019), 97.

${ }^{22}$ Departemen Agama RI, Pola Pengembangan Pondok Pesantren (Jakarta: Direktorat Jenderal Kelembagaan Agama Islam/ Direktorat Pendidikan Keagamaan Islam Dan Pondok Pesantren, 2003), 183.

${ }^{23}$ Targhib is a promise accompanied by persuasion so that someone likes to do good and avoid evil.. Tadzhibis a threat to cause fear is not correct.

${ }^{24}$ Abdullah Nashih 'Ulwan, Pendidikan anak dalam Islam (Jawa Tengah: Penerbit Insan Kamil Solo, 2012), 45.

${ }^{25}$ Lukman Hakim, Interview data, Agustus 2019. 
most important thing is that practice and theory must support and complement each other. ${ }^{26}$

The kyai inexplicitly sends a message about the urgency of Pesantren values articulated in behavior. Likewise, in the context of value articulation based on the value of Pesantren, school principals make the kyai the model of Pesantren values. Kyai according to educators in Pesantren are ideal figures that influence them through behavior, attitudes, and words.

Thus, the description as above shows that the process of forming the school principals' self-identity in the Pesantren Nurul Jadid is done in the form of self-understanding, parenting patterns, and role models or exemplary method. This shows that the formation of the school principals' self-identity in Pesantren Nurul Jadid involved past experiences and beliefs that gave rise to the continuity and consistency of self-attitudes. The formation of the principal's self-identity in the Pesantren Nurul Jadid gives meaning to the principal correctly, with the process involving experience, knowledge, and belief. The results of this study also indirectly indicate that the formation of selfidentity cannot be separated from the dyadic relationship between self and others.

The description as above, confirms that the formation of school principals' self-identity based on Pesantren through selfunderstanding is balanced by a religious and authoritative parenting pattern. Parenting in this dimension emphasizes the inculcation of values known as Human Factors and God Factor. The parenting pattern is carried out with a collaborative, persuasive approach and is based on exemplary, ibrah, targhib and tahdzib, so that self-identity leads to the alignment of vertical and horizontal relationships.

\section{PATTERN OF SELF-IDENTITY OF THE HEADMASTER BASED ON PESANTREN IN TRANSPERSONAL PSYCHOLOGICAL PERSPECTIVE}

The school principals' self-identity based on Pesantren in the perspective of transpersonal psychology in the form of spiritual awareness that occurs in the Pesantren Nurul Jadid is a manifestation from vertical and horizontal relationships. In this case, the spiritual

${ }^{26}$ Muhammad Nur Abdul Hafidz Suwaid, Mendidik Anak Bersama Nabi (Solo: Pustaka Arafah, 2004), 458. 
awareness that characterizes of school principals in Pesantren Nurul Jadid appears in behavior and words that reflect the awareness that their position as principals is a responsibility that they must shoulder and will be held responsible not only to parents of students, and community, but also responsibility to Allah. ${ }^{27}$

Awareness in this dimension is related to personality. Sigmund Freud in Waslam divides mental life into three levels, namely the subconscious, the unconscious, and the conscious. This subconscious contains all the elements that are not realized but can appear in consciousness quickly or rather difficult. Thus, in the unconscious nature will emerge any unconscious impulse or instinct but will encourage statements, feelings, and actions. ${ }^{28}$

The appearance of behavior that represents the school principals' self-identity in the Pesantrenbased school principals is based on beliefs or belief systems of a community. Principals' trust in Pesantren comes from studies of the meaning contained in the Qur'an and alSunnah. The study found a lot of evidence, that Islamic teachings encourage people to work hard, and give spirit and encouragement to the growth of culture and a high work ethic. Thus, the principal's identity under the auspices of the Pesantren Nurul Jadid is based on theological doctrine. Thus, the school principals' self-identity in pesantren is reflected by the high awareness of religion influences the actualization of the soul in daily life. Actualization in daily life is carried out in the form of mental and spiritual activities such as helping one another with others, respecting others, and internalizing universal values.

Someone who has spiritual awareness will be able to be flexible, ready to face and utilize suffering, deal with pain, quality of life inspired by greater vision and values, and holistic thinking. ${ }^{29}$ The spirituality explains about consciousness which is very important and becomes the main goal in life, and not just shadows, assumptions, and feelings towards other objects. Spiritual mind influences behavior in interacting with the work environment and gives cognitive power to

${ }^{27}$ Wicaksono, Interview data.

${ }^{28}$ Waslam, "Kepribadian Dalam Teks Sastra; Suatu Tinjauan Teori Sigmund Freud," Jurnal Pujangga 1, no. 2 (2015): 138-154.

${ }^{29}$ Zamzami Sabiq and M. As'ad Djalali, "Kecerderdasan Emosi, Kecerdasan Spiritual Dan Perilaku Prososial Santri Pondok Pesantren Nasyrul Ulum Pamekasan," Persona:Jurnal Psikologi Indonesia 1, no. 2 (n.d.): 53-65. 
the individual. ${ }^{30}$ This awareness eventually gives birth to spiritual harmony (spirit) and material harmony ${ }^{31}$ (lahiriah). Thus, the findings of the study is a clue that the principal's self-identity according to the perspective of transpersonal psychology in the form of spiritual awareness has relied on the teachings of Islam as stated in the Qur' an and Hadith (god oriented spirituality) and optimizing the potential and creativity of human beings (humanistic spirituality).

The next form of identity that characterizes the school principals is the ability to manage personal egos (trans-egos). The ability to manage personal ego becomes an inherent personality and is one of the school principals' self-identity according to the perspective of transpersonal psychology. Based on the results of the study, it was found that the ability of the school principals in managing ego is sustained by the operation of the two doors of self-awareness of the principal, namely the door of consciousness that faces the real world and the door of consciousness that faces the malakut. The school principals interpret work as part of worship performed by exerting all of their assets, thoughts, and remembrance to actualize or manifest their meaning as servants of God who must defeat the world and place themselves as part of the best society (khaira ummah). ${ }^{32}$

Control of the personal ego is part of emotional intelligence. According to Goleman who explained that emotional intelligence is the ability of a person to manage his emotional life with intelligence (to manage our emotional life with intelligence), maintain emotional harmony and its expression (the appropriateness of emotion and its expression) through the skills of self-awareness, self-control, motivation self, empathy, and social skills. ${ }^{33}$ Emotional intelligence is the use of emotions to control situations, distinguish feelings within

${ }^{30}$ Tri Niswati Utami, “Analisis Spritiual Value, Stres Kerja Pekerja Muslim Sektor Formal kota Medan," n.d., 24.institutional and industrial demand time and home work, good performance, demands adequate skills and productivity work well too. This condition causes the pressure by the workers and lead to job stress. Research method: using a two stage approach: qualitative and quantitative. Quantitative design uses one group pretest posttest study. Bivariate data analysis paired t test and PLS (Partial Least Square

${ }^{31}$ Material (outward) harmony is harmony related to the environment, both the nat ural environment (natural) and the human environment (social).

${ }^{32}$ Syamweil, Interview data.

${ }^{33}$ Daniel Goleman, Emotional Intelligence (New York: Bantam Books, 1995), 42. 
oneself in other individuals, as well as maintain focus and understand what is considered important. The level of emotional intelligence of people becomes better when they are proficient in handling emotions, motivating themselves and have high empathy and ability to manage relationships. Emotional intelligence in a person has a deep sense rooted in themselves to help them in building more balanced relationships with teachers, parents, and friends with positive moods. So emotional intelligence includes skills such as self-control, perseverance, enthusiasm and the ability to hold negative feelings and focus on positive feelings play an important role in determining success. Emotions can provide valuable insights for oneself to have better communication and emotional self-management roles such as stress, stress, morale, and poor quality of work in everyday life. ${ }^{34}$

The description as above asserted that the school principals' self-identity in Pesantren shows a modern human identity that wants to return to the sanctity of life with a spiritual pattern to gain psychological legitimacy with the presence of transpersonal psychology. The basic idea of transpersonal psychology is to try to see humans in harmony with religious views, that is, as beings with spiritual potential.

The results of this study are at the same time antithetical to what prevails and takes place in the West which has lost its supernatural sense. That, in some cases, caused a crisis of human identity as a impact of the shifting of divine values. In that context the powerless is the understanding of secularism and materialism..$^{35}$ Thus, the results of this study describe the conceptual building as follows:

${ }^{34}$ Baghdad Afero and Adman, "Peran Kecerdasan Emosional Sebagai Faktor Yang Mempengaruhi Kemandirian Belajar Siswa," Jurnal Pendidikan Manajemen Perkantoran 1, no. 1 (n.d.): 215-223.

${ }^{35}$ Komaruddin Hidayat, Tragedi Raja Midas: Moralitas Agama dan Krisis Modernisme (Jakarta: Paramadina, 1998), 273. 
Table: Scheme of Self Identity in Transpersonal Psychology Perspective

\begin{tabular}{cllc}
\hline Focus & \multicolumn{1}{c}{$\begin{array}{c}\text { Forming } \\
\text { Factors }\end{array}$} & Impact of Identity & $\begin{array}{c}\text { Substance } \\
\text { Category }\end{array}$ \\
\hline & $\begin{array}{l}\text { Self } \\
\text { understanding }\end{array}$ & Spiritual Awareness & \\
The Self-Identity Ego & & \\
of Headmaster & Parenting & Spiritual Awareness & Nafsani \\
Based on & style & Trans Ego & substance \\
Pesantren & The model of & Spiritual Awareness & \\
& figure role & Trans Ego & \\
\hline
\end{tabular}

\section{CONCLUSION}

Based on the description as above, there are two major conclusions. First, the process self-identity formation among the principals of Pesantren Nurul Jadid Paiton Probolinggo is done in form of self understanding, parenting style, and role models. These three things become the factors forming the identity of the principal of the school. Self-understanding shapes the principal's identity by equalizing religious and authoritative parenting patterns. Parenting in this dimension emphasizes the inculcation of these values, then known as Human Factors and God Factors. With a collaborative approach, a persuasive approach and role modeling, ibrah, and targhib and tahdzib used in Pesantren, self-identity that leads to the alignment of vertical and horizontal relationships is formed.

Second, the forms of principals' self-identity based on Pesantren according to the transpersonal psychology are spiritual awareness and the ability to manage the ego (trans-ego). This identity is a distinguishing and self-categorizing identity of the principals of Pesantren-based school from the perspective of transpersonal psychology. This identity requires spiritual harmony (ruhaniah) and material harmony (lahiriyah). In this dimension, the school principals' self-identity reflects a modern human who wants to return to the sanctity of life with a spiritual pattern gets psychological legitimacy with the presence of transpersonal psychology. The basic idea of transpersonal psychology is to try to see humans in harmony with religious views, that is, as beings with spiritual potential. 


\section{REFERENCES}

Afero, Baghdad, and Adman. "Peran Kecerdasan Emosional Sebagai Faktor Yang Mempengaruhi Kemandirian Belajar Siswa." Jurnal Pendidikan Manajemen Perkantoran 1, no. 1 (n.d.): 215-23.

Ayun, Primada Qurrota. "Fenomena Remaja Menggunakan Media Sosial Dalam Membentuk Identitas." CHANNEL Jurnal Komunikasi 3, no. 2 (October 1, 2015). https://doi.org/10.12928/ channel.v3i2.3270.

Crapps, Robert W. Gaya Hidup Beragama Autoritas yang Sedang Menjadi Mistik. Yogyakarta: Kanisius, 1993.

Departemen Agama RI. Pola Pengembangan Pondok Pesantren. Jakarta: Direktorat Jenderal Kelembagaan Agama Islam/ Direktorat Pendidikan Keagamaan Islam Dan Pondok Pesantren, 2003.

Emzir. Analisis Data: Metodologi Penelitian Kualitatif. Jakarta: Rajawali Pers, 2010.

Erikson, Erik, and Agus Cremers. Identitas dan Siklus Hidup Manusia: (Bunga Rampai 1). Jakarta: PT Gramedia, 1989.

Goleman, Daniel. Emotional Intelligence. New York: Bantam Books, 1995.

Hefniy, Hefniy. "Pergeseran Kepemimpinan Kyai dalam Mengembangkan Budaya di Pondok Pesantren Nurul Jadid Paiton Probolinggo." Disertasi, UIN Malang, n.d. http:// etheses.uin-malang.ac.id/12182/.

Hendrawan, Sanerya. Spiritual Management; From Personal Enlighment Towards God Corporate Governance. Bandung: Mizan, 2009.

Komaruddin Hidayat. Tragedi Raja Midas: Moralitas Agama dan Krisis Modernisme. Jakarta: Paramadina, 1998.

Lukman Hakim. Interview data, Agustus 2019. 
Martin van Bruinessen. Kitab Kuning, Pesantren, Dan Tarekat; Tradisi Islam. Bandung: Mizan, 1999.

Mundiri, Akmal, and Syafiqiyah Adhimiy. Religious Authoritative Parenting Berbasis Quantum Meaningfullness of Life; Melejitkan Potensi Raih Prestasi. Probolinggo: Pustakan Nurja, 2019.

Mundiri, Akmal, and Moch Tohet. "Contestation of Religious Identity in the Cyber World: A Case Study of Arrahmah.Com and VOA Islam Dealing with Religious Others on Facebook." Walisongo: Jurnal Penelitian Sosial Keagamaan 26, no. 2 (December 3, 2018): 391-416. https://doi.org/10.21580/ ws.26.2.3244.

Nurochim, Nurochim. "Sekolah Berbasis Pesantren Sebagai Salah Satu Model Pendidikan Islam Dalam Konsepsi Perubahan Sosial." Al-Tahrir: Jurnal Pemikiran Islam 16, no. 1 (June 24, 2016): 69. https://doi.org/10.21154/al-tahrir.v16i1.320.

Nurul Jadid, Pondok Pesantren. "Data Document about Alumni of Pondok Pesantren Nurul Jadid.” Pondok Pesantren Nurul Jadid, 2018.

—. "Data Document about Regulations and Obligations of Santri in Pondok Pesantren Nurul Jadid." Pondok Pesantren Nurul Jadid, 2019.

Pals, Daniel L. Seven Theories of Religion. Yogyakarta: IRCISoD, 2011.

Sabiq, Zamzami, and M. As'ad Djalali,. "Kecerderdasan Emosi, Kecerdasan Spiritual Dan Perilaku Prososial Santri Pondok Pesantren Nasyrul Ulum Pamekasan.” Persona:Jurnal Psikologi Indonesia 1, no. 2 (n.d.): 53-65.

Sarwono, Sarlito Wirawan. Psikologi Sosial Psikologi Kelompok Dan Psikologi Terapan. Jakarta: Balai Pustaka, 1999.

Suwaid, Muhammad Nur Abdul Hafidz. Mendidik Anak Bersama Nabi. Solo: Pustaka Arafah, 2004.

Syamweil, Faizin. Interview data, July 13, 2019. 
Thohiruddin, Thohiruddin. Interview data, July 12, 2019.

'Ulwan, Abdullah Nashih. Pendidikan anak dalam Islam. Jawa Tengah: Penerbit Insan Kamil Solo, 2012.

Utami, Tri Niswati. "Analisis Spritiual Value, Stres Kerja Pekerja Muslim Sektor Formal kota Medan,”.

Wahid, Abdurrahman. Menggerakkan Tradisi: Esai-Esai Pesantren. Cet. 1. Yogyakarta: LKis, 2001.

Waslam. "Kepribadian Dalam Teks Sastra; Suatu Tinjauan Teori Sigmund Freud.” Jurnal Pujangga 1, no. 2 (2015): 138-54.

Wicaksono, Didik. Interview data, July 12, 2019.

Winarni, Leni. "The Political Identity of Ulama in the 2014 Indonesian Presidential Election." Al-Jami'ah: Journal of Islamic Studies 52, no. 2 (December 24, 2014): 257. https://doi. org/10.14421/ajis.2014.522.257-269. 